\title{
A CATALOGUE OF THE FISHES OF ILLINOIS.
}

\author{
By Prof. DAVID S. JORDAN.
}

This catalogue is based primarily on the collections in the Illinois State Laboratory of Natural History, at Normal. These collections consist (a) of the material on which Mr. Nelson's * list was based, and (b) of a large collection made by Professor Forbes during the past summer (1877), chiefly in the streams of southern Illinois. The writer's own eollections in Illinois and adjacent states have also been drawn upon, as well as those contained in the United States National Iuseum. The various seattered notices of Illinois fishes have also been brought together as far as possible, thus giving all that is at present known of the distribution of the species within the limits of the state.

Reference has been made throughout this paper to the second edition of the author"s Manualt of Vertebrates, (quoted as "II. V.,") in which nearly all the species here mentioned are described. No synonony is given except that of Mr. Nelson's list, above mentioned, of which paper the present may be considered as, in a sense, a revised edition.

$A$ few species either new to seience or new to our fauna and therefore not noticed in the Manual, are here deseribed in full.

In all cases where I have found exact record of localities of species, these have been inserted. Species not yet taken in Illinois, but included in the catalogue on the strength of our general knowledge of their range, are indicated by a star $\left({ }^{*}\right)$.

*A Partial Catalogue of the Fishes of lllinois, by E. IV. Nelson, Bulletin No. 1, Illinois Museum of Natural History, October, $18-6$.

TA Mamual of the Vertebrate Animals of the Northern United States, including the district east of the Mississippi River and north of North Carolina and Tennessee-exclusive of Marine Species. by David Starr . Jordan, M. D., Ph. D., professor of Natural History in Butler University. Second edition, revised and enlarged. Chicago-Jansen. HeClurg \& Co. 1878. 


\title{
Subclass, TELEOSTEI.
}

\section{Order, TELEOCEPHALI.}

\section{Suborder, ACANTHOPTERI.}

\author{
Family ETHEOSTOMATID $A$, (the Darters.)
}

Genus PLEUROLEPIS, Agassiz.

\section{Pleurolepis pellucidus (Baird) Ag. Sand Darter, (M. V. 219., Nel- son, 35).}

Abundant in clear sandy streams, wherever such occur; therefore generally absent in the prairie region, but occurring in the Wabash valley and in the northwestern part of the state. The genus Pleurolepis, like Ammocrypta, has usually but one anal spine, although two have been generally ascribed to it. Pine Cr. and Rock R., in Ogle Co.

\section{Pleurolepis asprellus Jordan (sp. nov.) Rough Sand Darter.}

A species similar in form to $P$. pellucidus, but less transparent and much more completely scaled. The size is also much larger.

Body very long and slender, nearly cylindrical, about as in $P$. pellucidus, the depth about 8 in the length. Caudal peduncle long and slender, its length nearly 4 times in total. Head long and rather slender, $4 \frac{1}{5}$ in length; eyes very large, high up and rery close together, shorter than snout, having considerable vertical range.

Mouth not large, sub-terminal, horizontal, the upper jaw rather the longer. Upper jaw sub-protractile, the furrow separating it from the forehead very distinct laterally, but obliterated mesially, the skin covering the middle of the intermaxillaries being continuous with that of the rest of the forehead. Cheeks, opercles and sides of the crown covered with pectinated scales; opercular spine well developed. Teeth as usual, rather feeble. Squamation much more complete than in $P$. pellucidus. Sides and back with well-developed, closely imbricated scales, which are not imbedded as in P. pellucidus; the scales larger on the caudal peduncle than anteriorly. Jugular region, and belly between ventrals and anal, entirely naked; spacbetween bases of ventrals scaled; back of neck scaly; lateral line wells developed, with about 98 scales, 10 series above the lateral line. Fine large, the dorsals well separated, the spinous dorsal high, its anterior rays highest; second dorsal smaller and smaller than anal. Anal fin with a single rather flexible spine; caudal lunate, more concave than usual in darters. Pectorals and ventrals large, their tips about even, neither quite reaching the vent. Coloration of smaller specimens much as in $P$. pellucidus, accord- 
ing to Prof. Forbes rather opaque in life; sides with 8 to 10 dark, squarish blotches, quite small and far apart; a blackish shade forward from eye and a dusky shade across operele.

Numerous specimens in the State collection, some about $2 \frac{1}{3}$ inches long, taken by Prof. Forbos in the Little Wabash River, (a saudy stream,) in Effingham Co., in July. Two others, larger, one of them, the type of this description, $4 \frac{1}{3}$ inches long, collected by Mr. C. K. Worthen, in a small rocky tributary of the Mississippi, in Hancock Co. These were described as very highly colored when fresh, presenting "almost all the colors of the rainbow."

Genus PERCINA, Haldeman.

3. Percina caprodes (Raf.) Grd. Log Perch. Hog Fish. (1I. V. 219 ; B. I. M. 36.)

In clear rapid waters; probably generalìy distributed. Vermilion R., Calumet R., Wabash R., Pine Cr., (Ogle Co.)

4. * Percina manitou Jordan. Manitou Darter. (II. V. 220.)

From Lake Manitou, a tributary of the Wabash in Indiana; also from Wisconsin.

Genus ALVORDIUS, Girard.

5. Alvordius maculatus Grd. Black Sided Darter; Blenny Darter. (II. V. 220 ; Etheostoma blennioides Nelson, 35.)

In clear waters-generally distributed. Ogle Co.; Tazewell Co.; Clear Cr., Union Co.

6. Alvordius phoxocephalus (Nelson) Cope and Jordan: Sharp-Nosed Darter. (M. V. 221, Etheostoma phoxocephalum Nelson, 35.)

Illinois River: a few specimens in the collection; also from Tennessee and Kansas.

Genus ERICOSMA, Jordan.

7. * Ericosma evides Jordan \& Copeland. Gilded Darter. (M. V. 221. Etheostoma evides Nelson 36.)

At present known only from White River, a tributary of the Wabash in Indiana.

Genus IMOSTOMA, Jordan.

8. Imostoma shumardi (Grd.) Jordan. Big-headed Darter. (M. V. 222.)

Specimens in the Indiana State collection from Wabash River in Crawford Co., and in the National IIuseum from the Illinois River in Ia Salle Co. 
Genus RHEOCRYPTA, Jordan.

9. *Rheocrypta copelandi Jordan. Copeland's Darter. (M. V. 222.) Known only from White River, near Indianapolis.

Genus DIPLESIUM, Rafinesque.

10. Diplesium Zlennioides (Raf.) Jordan. Green-Sided Darter. (M. V. 222.)

Abundant in the Wabash valley, Crawford Co.

Genus BOLEOSOMA, Dekay.

11. Boleosoma olmstedi (Storer) Agassiz. Tessellated Darter. (M. V. 224 ; Nelson, 35). Lake Michigan, Ogle Co.

12. Boleosoma maculatum Agassiz. Johnny Darter (M. V. 224; Boleosoma brevipinne Nelson, 36.)

Common throughout the state, in clear streams. Pine Cr., Ogle Co.; Illinois R., Pekin; Normal; Drury Cr., Union Co.; Clear Cr.

[13. Boleosoma camurum, Forbes, n. s.

In re-examining the collections of the Jaboratory for the purpose of adding to this paper the details of distribution and other minor points, I made a few observations on some Etheostomatidae and Cyprinidae which seem worthy of record, and I therefore insert them here, at the suggestion of Dr. Jordan.

Specimens from several localities in the state, mixed sometimes with Boleosoma maculata and sometimes with Boleiclthys eos, prove, on closer examination, to be a Boleosoma quite distinct from maculata, and apparently undesscribed.

The general appearance is much like that of maculata, but the lateral line is incomplete, the species is more slender, has a greater number of vertical rows of scales, a blunt nose and a scaly head.

The length is from 45 to $50 \mathrm{~mm}$. Depth $5 \frac{1}{2}$ to 6 in length, caudal peduncle $3 \frac{1}{2}$, head 4 to $4 \frac{1}{2}$. Eye $3 \frac{2}{3}$ in head, nose $\frac{3}{3}$ eye, aud almost truncate. Mouth inferior, horizontal, upper jaw the longer, and decidedly protractile. There are no naked areas, except a narrow strip before the dorsal. Vertical rows of scales 54 to 57 , with the lateral line usually extending over from 23 to 35 scales. 5 longitudinal rows above lateral line. In a few specimens 35 to $50 \mathrm{~mm}$. long, there is only a trace of a lateral line on 4 or 5 scales. Scales smaller before dorsal, about $\frac{4}{5}$ those on sides.

D. IX or $\mathrm{X}-10$ to 12 , A. I-8 or 9 . Upper D. half as high as long, about $\frac{5}{6}$ height of $2 \mathrm{~d} D$., and contiguous to it. Second $\frac{7}{10}$ length of first, and $\frac{2}{5}$ longer than anal. Anal spine weak and short, length of fin $\frac{4}{5}$ its height. Ventrals and pectorals reach the same point, $\frac{2}{3}$ to vent. 
Color in alcohol like that of $B$. macnlata. A row of obout 10 irregular blotehes along the side,-sometimes obseure, especially before-and six larger ones on the back. Mlany smaller, irregular, angular specks be. tween these rows. Belly immaculate. Stripe before eyes and bloteh on operele. Median fins banded, others plain. Cache R. and Clear ('r., Union Co.: Johnson Co.; Pekin.

This speeies makes it necessary to drop the complete lateral line as a character of Boleosoma. In fact, this is often wanting on four or five posterior scales in B. maculato. S. A. F.]

\section{Genus NANOSTOMA, Putnam.}

14. Nanostoma zonale (Cope) Jordan. Zoned Darter. (M. Y. 225.)

Many specimens from Pine Creek in Ogle Co.

Genus NOTHONOTUS, Agassiz.

15. *Nothonotus camurus (Cope) Jordan. Blue-Breasted Darter. (11. V. 2.25; Poecilichthys uiger Nelson, 34.)

A few specimens from White River in Indiana.

Genus PECILICIFTHYS, Agassiz.

16. Pecilichthys variatus (Kirtland) Agassiz. Bude Darter. (1I. $T$. 2.26; Prcilichthys caruleus Nelson, 34.)

Generally common in clear or grarelly streams-especially so in the Wabash Valley: Farmington; Rock R., Ogle Co ; Pekin, IIl.

17. Pacilichthys spectabilis Agassiz. Striped Blue Darter. (I. V. 2.27; Nelson, 3.)

With the preceding; rather less common and more fond of ascending small streams: often found in waters with a muddy bottom. Effingliam Co.; Machinaw Cr., NicLean Co.; Pine Cr., Ogle Co.; Cache R., Drury Cr., Clear Cr., and mud holes in Union Co.

\section{[18. Pucilichthys asprigenis Forbes, n. s.}

Among some specimens from Pekin, Ill, whose label as Precilichthys spectubilis had apparently served to disguise them, I observed a number with scaly cheeks. Dr. Jordan has decided that these are neither spectabilis, nor jessix, and I bave therefore described the series as a new species, although the wide variation of so-called specifie characters presented by them suggests that several species of this gemus may ultimately have to be merged. I have not been able, however, with a large number of specimens to trace the one wholly into the other, and I therefore leave them distinct for the present. 
General appearance much like that of $P$. spectabilis, from which it differs in the scaly cheeks, the more complete lateral line and the greater number of vertical rows of scales. In spectabilis the cheeks are either wholly bare, or a few scales appear behind and below the eye. In asprigenis they are either wholly covered, or naked only on the lower fourth. The vertical rows vary in my specimens of spectabilis from 38 to 43 (counting only complete rows),-in asprigenis from 48 to 50 . In the former, the lateral line extends over from 25 to 31 scales-in the latter from 34 to 41 .

The head is small and pointed, the eye large, (longer than snout,) the outlines regularly curved, the body compressed and rather deep, the mouth terminal, oblique, and the jaws about even.

The dorsal fins are sometimes separated by distances varying from the length of half a scale to a scale and a balf, but are occasionally quite continuous, the two being united by membrane.

Length 35 to $45 \mathrm{~mm}$. Depth $4 \frac{1}{4}$ to $4 \frac{3}{4}$ in length; head $3 \frac{3}{4}$ to 4 ; eye in head $3 \frac{1}{3}$ to 4 ; nose about $\frac{3}{3}$ the eye. Width at pectorals 8 to 10 in length; at middle of second dorsal, 12 to 15 . The caudal peduncle is twice long as high. Longitudinal rows 5 . Breast always naked, opercle wholly as scaly, back wholly scaled before the dorsal, or a narrow strip left bare.

The first dorsal consists of from 9 to 12 spines. Its height is from $\frac{1}{2}$ to $\frac{1}{3}$ its length, and $\frac{2}{3}$ the height of the second dorsal. The latter contains from 10 to 12 rays, of which, in one case, the first was a stout sharp spine (XI-I, 11). Its length is $\frac{3}{5}$ that of the first, and $\frac{3}{5}$ greater than that of the anal. The anal consists of two spines and 7 or 8 soft rays, the longest ray reaching to the middle of the caudal peduncle. 14 specimens examined. Taken in small creek near Pekin, Ill.

The naked cheeks and contiguous dorsals are evidently not good generic characters of Pocilichthys, S. A. F.]

Genus ETHEOSTOMA, Rafinesque.

19. Etheostoma flabellare Rafinesque. Fan-taimed Darter. (M. V. 227; Pocilichthys flabellatus Nelson, 34.)

In clear waters in the southern part of the state. Specimens from Clear Cr., Union Co., and from Wabash River.

Var. lineolatum (Agassiz) Jordan. Lined DARTER. (M. V. 227 ; Pocilichthys lineolatus Nelson 34.) Clear streams in northern Illinois. Rock River, Ogle Co. Finish.

20. *Etheostoma squamiceps Jordan. Scaly-headed Darter. (M. V. 228.)

Known only from western Kentucky.

Genus BOLEICHTHYS, Girard.

21. Boleichthys eos Jordan \& Copeland. Red Sided Darter. (M. V. 228 ; Nelson, 34.)

In clear cold streams throughout the state. Effingham Co., Johnson Co. 
[22. Boleichthys elegans, Gir.

Several specimens from Union and Johnson counties, apparently belong to this species. The following deseription is made up from Dr. Jordan's account of the species in Ann. N. Y. Lye., XI, 308, modified to include my larger specimens, some of which are 2 inches long.

Body short, chubby and compressed, bearing some resemblance in form to Microperca punciulata. Mouth moderate, with equal jaws.

Dorsal fins usually distinctly separate, the second $\frac{2}{3}$ as long as the first and twice as long as anal. Vertical rows of scales varying from 42 to 56. Jateral line distinct on from 13 to 30 seales, arched high over peetorals, running parallel with the rounded nuchal region, separated from the dorsal fin by but 3 rows of seales. Head and neck scaly, throat bare, as well as a small space behind poetorals and ventrals.

Head $3 \frac{3}{4}$ to 4 in length, depth $4 \frac{3}{4}$. Eye 3 to 4 in head Width at pectorals (in adult) $6 \frac{3}{4}$ in length. Fin rays, D. IX or $\mathrm{I}-9$ to $11 ; \mathrm{A}$. II -7 or 8 . Color greenish with dark specks, in Illinois specimens with about 10 dorsal bars, and 6 lateral blotches on posterior half of side. Dark line before eye and in adults another below eye, and an opereular blotch. S. A. F.]

Genus MICROPERCA, Putnam.

23. Microperca punctulata Putnam. Least Darter. (M. V. 229 ; Nel_ son, 34.)

In clear streams. Drury Cr., Union Co.; Crystal Lake, MeHenry Co.; Kane Co.

Family PERCIDAE, (the Perches.)

Genus $P E R C A$, Linnæus.

24. Perca americana Schranek. Common Yellow Perch, Ringed Perch. (M. V. 229; Perca flavescens Nelson, 36.)

Very abundant in Lake Michigan and all its tributaries, and to a less degree in all the tributaries of the Mississippi River in the northern third of the state. In the southern part of the state it is very rarely or never found, its range, like that of Eupomotis aureus, being bounded by lines of latitude. Peoria and Pekin, Ill.; L. Mich.

Genus STIZOSTETHIUM, Rafinesque.

25. Stizostethium canadense (Smith) Jordan. Sauger. Sand Pike, Ground Pike, Gray Pike (1. V. 230. Stizostedium griseum Nelson, 36.)

Generally abundant in the lakes and all the larger streams. Is. Mich.; Ill. R. at Peoria, \&c. 
26. Stizostethium vitreum (Mitch.) Jordan \& Copeland. WALL-EYED Pike, Salmon, Dory, Glass-eye, Yellow Pike. (M. V. 230 ; Stizostedium americanum Nelson, 36.)

Generally abundant in the lakes and larger bodies of water, especially nortliward. Ill. R. at Peoria.

var. salmoneum (Raf.) Jor. White Saluion, Blue Pike. (M. V. 230. Nelson, 36.) Ohio River and its larger tributaries.

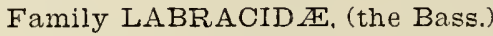

Genus ROCCUS, Mitchill.

27. Roccus chrysops (Raf.) Gill. White Bass. (M. V. 232; Nelson, 36.) Generally abundant in the larger streams northward. Lake Michigan; Quincy; Henry.

Genus MORONE, Mitchill.

28. Morone intermpta Gill. Short-striped White Bass (II. V. 232: Nelson, 36.) Common in the southern half of the state in the larger streams. Illinois R. at Henry; Mackinaw Creek, McLean Co.; Cairo.

Family CENTRARCHID Æ, (the Sun-fishes.)

Genus MICROPTERUS, Lacepede.

29. Micropterus pallidus (Raf.) Gill \& Jordan. Large-Mouthed BLACK Bass, Oswego Bass (M. V. 236; Micropterus nigricans Nelson, 36)

Everywhere abundant, especially northward; found in sluggish waters and small streams, more frequently than the next. Lake Michigan; Rock R., Ogle Co.; Calumet R.; Crystal Lake: Running Lake and Clear Creek, Union Co.; Wabash River ; Mackinaw Cr., MeLean Co.

30. Micropterus salmoirles (Iac.) Gill. Sirall-Mouthed Black Bass, Moss Bass. (II. V. 236; Nelson, 37.)

Everywhere common, seeking the river channels more than the preceding does. Rock R., Ogle Co.: III. R.

Genus AMBLOPLITES, Rafinesque.

31. Ambloplites rupestris (Raf.) Gill. Rock Bass, Red Eye, Goggle EYE. (M. V. 237; Nelson, 37.)

Generally abundant throughout the state. NeLean Co.; Henry; Ogle Co. 
Genus CH.ENOBRITTUS, Gill.

32. Chanobryttus gulusus (C. \& V.) Gill. War-nouth, Black Sux-fish. (M. T. 237; Nelson, 37.)

Rather common. Very abundant in sonthern Illinois. Prof. Forbes has specimens from Illinois River, and I have taken it in Lake Michigan, and in lakes of Northern Indiana tributary to Wabash River. Mackinaw Cr.; Big L., Jackson Co.

Genus APOMOTIS, Rafinesque.

33. Apomotis cyanellus (Raf.) Jor. Blue-spotted Sun-Fish. (M. V. 239; Telipomus cyanellus and T. microps Nelson, 37.)

Generally abundant, ascending small streams. Embarras River, Calumet R., Illinois R., Cache R., mud-holes on bottoms in Union Co. and Johnson Co., Effingham Co., all small streams in MeLean Co.; Fountain Bluff, Jackson Co.

Genus LEPIOPOMC'S, Rafinesque.

34. Lepiopomus macrochirus Raf. Cinain-sided Sun-Fisir. (M. V. 239 ; Telipomus nephelus Nelson, 37.)

Not very common; I have one specimen from Illinois River and several from White River in Indiana.

35. *Lepiopomus anagallinus Cope. Ren-spotted Sun-Fisil. (M. V. 240.)

Salt River, Ky., where it is abundant. Not yet noticed from Illinois, although it doubtless occurs in the state.

36. Lepiopomus pallidus (Mit.) Gill \& Jordan. BuUE Sun-Fish, CopPER-NOSED Brean. (II. T. 241: Ichthelis incisor and I. speciosus Nelson, 37.)

The most abundant of the sun-fishes. Crystal Lake, Illinois River, Calumet R., L. Michigan, Wabash River, Quincy.

37. Lepiopomus ischyrus Jordan \& Nelson. (M. V. 241; Ichthelis aquilensis Nelson, 37.)

The two original types of this species are all yet known-the one in the Illinois State Laboratory from Illinois River, the other in Mr. son's collection from Calumet River. Renewed examination of Nelthe former specimen las convineed me of its distinctness from $L$. pallichs. The type specimen has palatine teeth, unlike $L$. pallidus. Pomotis aquilensis Girard is Yenotis breviceps, a Texas species. 
Genus XENOTIS, Jordan.

38. Xenotis megalotis (Raf.) Jordan. Blue and Orange Sun-Fish. (M. V. 242; Ichthelis megalotis and I. sanguinolentus Nelson, 38.)

Generally abundant. Illinois River; Clear Cr., in Union Co., Wabash R., Mackinaw Cr., Fox R.

39. * Xenotis aureolus Jordan. GiLded Sun-FisH. (M. V. 243 ; Ichthelis macrochira Nelson, 38.)

Probably abundant in small streams, but not certainly identified from the state.

40. * Xenotis lythrochloris Jordan. Blue and Green Sun-Fish. (M. V. 243.)

Abundant in small streams tributary to the Wabash in Indiana, but not yet recorded from Illinois.

41. Xenotis inscriptus (Agassiz) Jordan. Blue-Green Sun-fish. (M. V. 243 ; Ichthelis inscriptus Nelson, 38.)

Moderately common in grassy ponds and streams in the southern part of the state. Wabash R., Cairo.

42. Xenotis peltastes (Cope) Jordan. (M. V. 243; Ichthelis anagallinus Nelson 38.)

Probably not very common. I have seen the specimen referred to by Mr. Nelson from Hox R.; and I have one or two more from the Wabash in Indiana.

Genus EUPOMOTIS, Gill \& Jordan.

43. Eupomotis aureus (Wall.) Gill \& Jordan. Common Sun-Fish. PumpKIN Seed. (M. V. 244 ; Pomotis auritus Nelson, 38.)

Very common throughout the northern third of the state, its abundance and distribution being the same as of the Yellow Perch. Peoria, Crystal Lake, Ogle Co., Henry, Lake Michigan; Rock River.

44. Eupomotis pallidus (Ag.) Gill \& Jordan. Pale Sun-Fish. (M. V. 244.)

Probably not common. I have seen specimens from near St. Louis. The resemblance of this species to Lepiopomus pallidus is very strong.

Genus COPELANDIA, Jordan.

45. * Copelandia eriarcha Jordan. (M. V. 246.)

As yet known only from streams near Milwaukee. It doubtless occurs in other tributaries of Lake Michigan. 
Genus CENTRARCHUS, Cuvier.

46. Centrarchus irideus (Lac.) Cuv. et Val. Shining Bass. (M. V. 246 ; Nelson, 37.)

Numerous specimens from the southern part of the state, referable to the southern Centrarchus irideus, but not typical specimens of that species, being in some respects intermediate between $C$. irileus and $C$. macropterus. Distinct as these two species appear, they may be found to intergrade so that they will have to be inerged into one. In form of body and size of mouth these Illinois specimens are exactly irideus, but the ventral spine is more elongate, reaching the first anal spine, and the fins are rather higher than is usual in irideus. The dorsal fin in the young specimens has a large jet-black spot, strongly ocellated. The larger specimens examined have the dorsal plain. Union Co., Jolinson Co.

Genus POMOXYS, Rafinesque.

47. Pomoxys nigromaculatus (Les.) Grd. Grass Bass, Calico Bass, BarFish, Bitter-Head. (M. V. 247; Pomoxys hexacanthns Nelson, 37.)

Generally very abundant, especially in the northern part of the state. In the southern part of the state; the next species takes its place to a great extent. Peoria, Quincy, Chicago, Rock River, Henry.

48. Pomoxys annularis Raf. Croppie, New Light, Campbeldite, Bachelor. (M. V. 247; Nelson, 37.)

Abundant everywhere in the tributaries of the Ohio and Mississippi, especially southward. Pekin, Peoria, Quincy; Wabash R., Ohio R., Mud-holes in bottoms, Johnson Co., Union Co., Mackinaw $\mathrm{Cr}$.

Family ELASSOMATID $Æ$, (the Elassomes.)

Genus ELASSOMA, Jordan.

49. Elassoma zonatum Jordan. (M. V. 248.)

A large number of specimens of this singular little fish were obtained by Prof. Forbes in ponds and sluggish waters in Union County. From these the anatomy of the species has beenpartly made out, and the affinities of the genus have probably been ascertained. As suspected by me when Elassoma was first discovered, its relations are with Aphododerus, and it will doubtless constitute a separate family, which should be placed next to the Aphododeridix. The resemblance of both to the Umbridæe probably indicate real affinities. None of Professor Forbes' speci. mens are an inch in length. At the time of collection they were supposed to be the young of Aphododerus. In these specimens the black shoulder spot is feeblc and there are three dark spots at the base of the caudal, vertically placed, imitating the black caudal bar in Melanura. The fin formula 
is not exactly as originally counted in Elassoma zonatum. This last count is however correct, while the first, being made without the assistance of a microscope, may be erroneous. It is best to consider the Illinois, Arkansas and Texas specimens as identical, at least at present.

Fin formula. Dorsal IV, 10, rarely IV 9 . Ventrals, I, 5, Anal III, 5, branchiostegals 5, vertebre 28. Teeth in lower jaw stout, conical, slightly curved, their length about half the depth of the dentary bone; these teeth, for a part of the way at least, in 2 to 4 rows; similar teeth on the premaxillaries in 2 or 3 rows; no teeth on vomer or palatine or on pterygoids ; lower pharyngeals narrow, apparently exactly as in Aphododerus, some what triangular, not united, with a few conic teeth, very sharp and slender; gill rakers small and short, tubercle-like; nostrils double, close together; opercular bones and proorbital not serrated. Scales cycloid; about eleven deep furrows on the imbedded part of each; concentric striæ strong. No lateral line. Vent normal.

The Elassomatidx then differ from the Aphododeridx in the position of the vent, in the dentition, (Aphododeridx having teeth on the vomer, palatine and pterygoids, ) in the number of ventral rays, and in the want of serratures to the preoperculum and preorbital, the edges of those bones being pectinated in the Pirate Perches.

\section{Family APHODODERID E, (the Pirate Perches.)}

Genus APHODODERUS, Le Sueur.

50. Aphododerus isolepis (Nelson) Jordan. Western Pirate Perch. (II. V. 249; Sternotremia isolepis Nelson, 39.)

This species is very closely related to the eastern $A$. sayanus, but apparently differs in the smaller scales and the presence of but three dorsal spines. The other has more frequently four spines, but often only three are developed. The scale formula of $A$. isolepis is subject to some variation. The following is the count of the number of scales in longitudinal series in ten specimens: $48,48,50,50,50,51,53,53,54,55$.

A study of the position of the vent in $A$. isolepis has developed some singular things. It becomes evident from the examination of a large series that the position of the vent is not a character of generic importance, as was supposed when the genus Stemotremia was proposed, nor is it apparently an individual or a sexual character as has been since suggested. The observations of Professor Forbes, verified by myself, appear to show that the position of the vent is dependent on the age of the fish. In the adult the vent is jugular, close behind the little projecting knob at the throat. In the youngest specimens examined, it is more or less behind the ventral fins. In specimens intermediate in size, its position is intermediate, the degree of advancement being proportionate to the size of the fish.

Occasional irregularities occur, but the above rule holds so generally that it can not be merely accidental. From it I infer that in the very young the position of the vent will be found to be as usual in Percoid fishes; as in the young flounder the eyes are symmetrical, but as the fish grows older, its aberrant characters become developed. 
The following table shows the position of the vent in 26 specimens.

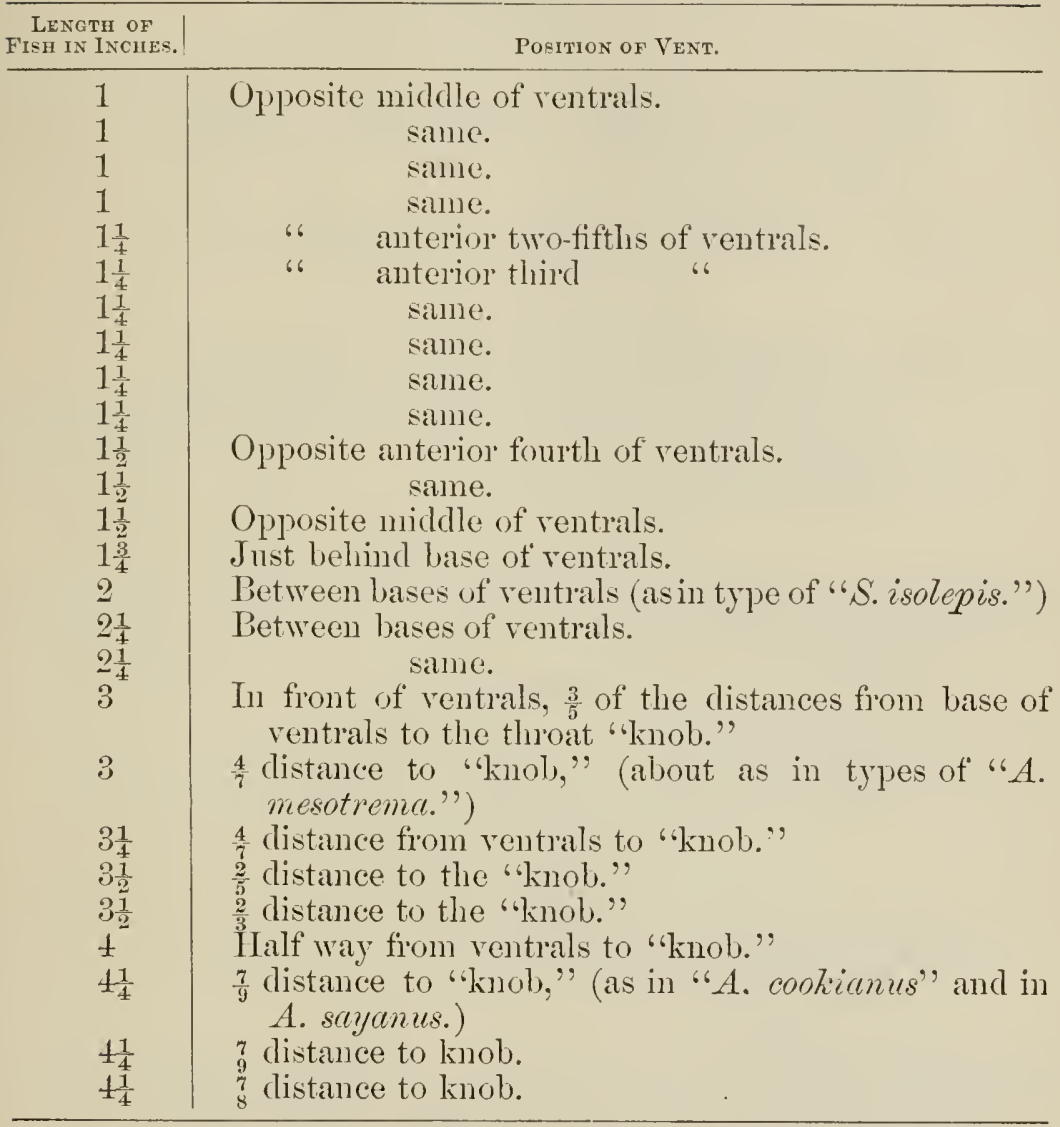

No other conclusion seems possible from the above exeept that the vent moves forward as the fish grows older, by the lengthening of the horizontal part of the intestine or "rectum" of the fish. Sternotremia isolepis is the young, Sternotremia mesotrema the half-grown and Aphododerus cookianus the adult of one and the same fish.

Aphododerus isolepis occurs in sluggish waters and bayous throughout the state. I have seen specimens from Calumet River, from numerous streams and sloughs in the southern part of the state and from the Wabash River at Mount Carmel,- - the latter"collected at different times by Robert Ridgway and Robert Kennicott. Union and Johnson counties. 
Family SCI $\mathbb{E}$ ID $Æ$, (the Maigres)

Genus HAPLOIDONOTUS, Rafinesqe.

51. Haploidonotus grumiens Raf. Sheepshead, Croaker, Grunting Perch, Drua, White Perch. (M. V. 250. Nelson 40.)

Common in all the lakes and larger streams throughout the state. La Salle; Penria.

Family COTTID $Æ$, (the Sculpins.)

Genus TRIGLOPSIS, Girard.

52. Triglopsis stimpsoni Gill (Mss). Deep Water Sculpin.

A species of this genus, which has received the above manuscript name, but which has never been described, occurs in the deeper waters of Lake Michigan.

Geuus URANIDEA, Dekay.

53. Uranidea lumlieni Hoy. Kunlien's Bull-head. (M. V. 253 ; NELSON 41.)

Deep water in Lake Michigan.

54. Uranidea hoyi Putnam. (M. V. 253; Nelson 41.)

Deep water in Lake Michigan.

Genus POTAMOCOTTUS, Gill.

55. Potamocottus alvordi (Grd) Gill. Alvord's Bull-Head. (M. V. 254, Pegedichthys alvordii, Nelson 41.)

Rock River.

56. *Potamocottus wilsoni (Grd) Gill. Wilson's Bull head. (M. V. 255.)

White River, Indiana, and probably also in Illinois-a doubtful species.

57. *Potamocottus meridionalis ( Grd) Gill. Cave Bull-head, Goblin, Bцob, Muffle-Jaws. (M. V. 254.)

Streams in the limestone region-often found in caves ; abundant in Southern Indiana, but not yet recorded from Lllinois.

Genus TAURIDEA, Jordan \& Rice.

58. Tauridea spilota (Cope) Jordan \& Rice. Cow-Faced Sculpin. (M. V. 255; Cottopsis ricei Nelson 40).

In deep water in Lake Michigan. 


\section{Suborder ANACANTHINI.}

Family GADID $\mathbb{E}$ (the Cod-flshes.)

Genus LOTA, Cuvier.

59. Lota lacustris (Walbaum) Gill. Lina, Burbot, Lawyer, Eelpout, Cusk. (M. V. 257, Nelson 42.)

Very abundant in Lake Michigan; stray specimens rarely taken in Illinois River, and in the Ohio and Mississippi. 'These probably have escaped through the canals.

\section{Suborder HEMIBRANCHII.}

Family GASTEROSTEID $\approx$, (the Sticklebacks.)

Genus $E U C A L I A$, Jordan.

60. Eucalia inconstans (Kirt.) Jordan. Black Stickleback. (M. V. 259, Nelson 42.)

Abundant in small streams in the northern part of the state only. Rock R, Pecatonica R., tributaries of Lake Michigan; Crystal L., MeHenry Co.

Genus PYGOSTEUS, Brevoort.

6I. Pygosteus occidentalis (C. \& V.) var. nebulosies (Ag.) Jor. MANY Spined Stickleback. (11. V. 260, Nelson 42.)

Lake Michigan-rather abundant in deep water.

\section{Suborder PERCESOCES.}

Family ATHERINIDE (the Silversides.)

Genus LABIDESTHES, Cope.

62. Labidesthes sicculus Cope. Silversides. (II. V. 261, Nelsou 42.) Generally abundant through the state, especially in ponds and bayous. Crystal L., McHenry Co ; Creeks, Peoria Co.; Rock R., Ogle Co.; Ill. R., Pekin; Mackinaw Cr., MeLean Co.

\section{Suborder HAPLOMI.}

Family CYPRINODONTID $\mathbb{E}$, (the Toothed Minnows.)

Genus FUNDULUS, Lacepede.

63. Funduhus diaphanus (I S.) Ag. Barren Knllifish. (M. V. 263, Nelson 42.)

Very abundant in lakes and clear or sandy streams in the northern part of the state. In Lake Michigan it abounds about the sandy mouths of tributaries, keeping in schools in the shallow water near the edge. Calumet $R$. 
64. Fundulus menona Jordan \& Copeland. (M. V. 263.)

Rock River; Crystal Lake, McHenry Co.

Genus ZYGONECTES, Agassiz.

65. Zygon'ctes notatus (Raf.) Jor. Top Minnow. (M. V. 264, Nelson 42.)

Generally abundant in sluggish waters and canals, especially southward. Ill. R. at Pekin; Livingston Co.; Jackson Co.

66. Zygonectes melanops (Cope) Jordan. Black-eyed Top Minnow. (II. V. 264.)

Numerous specimens of this species were obtained by Professor Forbes in the streams and ponds of the southern part of the state. They agree exactly with Prof. Cope's description of his Haploclilus melanops from the Neuse River in North Carolina. The wide distribution of this species is rather unexpected. Cache $\mathbf{R}$. and tributaries, Johnson Co.

67. Zygonectus dispar Agassiz. Striped Minnow. (M. V. 264, Nelson 42.)

Generally abundant in lakes, ponds and sluggish streams through the state, swimming in schools near the surface, slowly as if it were hard work. Specimens obtained by Prof. Forbes in the southern part of the state, are larger than any hitherto noticed, being more than two inches in length. Large specimens show a dark spot under the eye, somewhat as in the preceding species but fainter. Pekin; Beardstown; ponds and streams, Union and Johnson Counties.

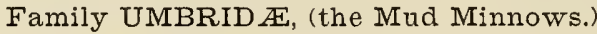

Genus MELANURA, Agassiz.

68. Melanura limi (Kirtland) Ag. Mud Minnow, Mud Dace, Dog-Fish. (M. V. 265, Nelson 43.)

Very abundant in ditches, muddy streams and prairie sloughs; found throughout the state, but much commonest northwards; numerous specimens from mud-holes in the bottoms of Johnson and Union Counties. Common in ditches near Crystal L., McHen. ry County.

\section{Family ESOCID $Æ$, (the Pikes.)}

Genus ESOX, Linnæus.

69. Esox notilior Thompson. Muskallunge. (M. V. 266, Nelson 43.) In Lake Michigan and, according to Mr. Nelson, said to occur in some of the small lakes of the northern part of the state. 
70. Esox lucius L. Pike, Grass Pickerel. (M. V. 266; E. lucius varestor, and E. boreus, Neison 43.)

Very abundant in all large streams in the northern third of the state, its distribution being similar to that of l'erca. Rock R., IIl. R.

71. Esox salmoneus Raf. Little Pickerel. (I. V. 267 ; E. salmoneus and E. umbrosus Nelson 43.)

Everywhere very abundant in ponds and bayous: especially common in ponds in Union Co.; also specimens from Fox R., and Ill. R. at Pekin.

72. Esox cypho Cope. Humpback Pickerel. (M. V. 267 ; Nelson 43.) The specimen referred to by Mr. Nelson, from the Fox River at Geneva, is the only one which I have seen from the state. .

[73. Esox ravenelli? Holbr.

A small, barred pickerel from Union Co., much more slender than salmoneus, with smaller scales, longer dorsal and anal fins, and different proportions generally, is perhaps referable to this species. It measures $2 \frac{7}{8}$ inches to the caudal. Depth $7 \frac{1}{3}$ in length, head $3 \frac{1}{5}$, depth of head 10 and width of head 12. Eye $2 \frac{3}{4}$ in nose (to tip of lower jaw) and $5 \frac{3}{4}$ in whole head, its depth equal to the deeply grooved inter-orbital space. The middle of the head is at the front margin of the pupil.

The dorsal commences half its length in front of the anal. The paired fins are very short (V. $3 \frac{1}{3}$ in head, $P \frac{1}{2}$.) The pectorals are nearer ventrals than front of premaxillary, and the ventrals are midway between pectorals and anal.

Obseure vomerine teeth extend further back than the palatine bands.

The cheeks and opercles are wholly scaly. Iat. 1. 125 seales, longitudinal rows 27 , from dorsal to anal. D. 14 (complete rays), A. $14, \mathrm{~V} 10$, Br. 14.

Color in alcohol dusky, with 12 yellowish, nearly vertical bands, plainest behind, narrow above, but widening below into triangular blotches, which merge in the pale color of the belly. A dark stripe extends from the tip of the nose to the hind edge of the opercle, and a vertical bar downward from the eye. The fins are all dusky. S. A. F.]

Family AMBLYOPSIDE, (the Blind Fishes.)

No species of Blind-fish has yet been recorded from Illinois.

\section{Suborder ISOSPONDYLI.}

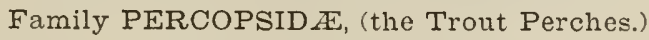

Genus PERCOPSIS, Agassiz.

74. Percopsis guttatus Ag. Trout Perch. (M. T. 270; Nelson 43.) Very abundant in Lake Michigan, caught by the hundred by boys from the Chicago wharves. Occasionally found in the larger streams through the state. 
Family SALMONID $A$, (the Salmon.)

Genus CRISTIVOMER, Gill \& Jordan.

75. Cristivomer namaycush (Walbaum) Gill \& Jordan. Great Lake Trout, Mackinaw Trout, Longe, Togue. (II. V. 359; Salmo namaycush Nelson 44.)

Abundant in Lake Nichigan.

Genus COREGONUS, Linnæus.

76. * Coregonus tullibee Rich. (M. V. 361.)

This strongly marked species occurs in Lake Superior, and itor a closely related one, known as the "mongrel White Fish,"-is found in the eastern part of Lake Erie. (Sterling-Milner.) It has not yet been recorded from Lake Michigan.

77. Coregonus nigripinni: (Gill) Jor. Blue Fin, Black Fin. (M. V. 362 ; Argyrosomus nigripinnis Nelson 44.)

Abundant in the deep water of Lake Michigan. Specimens may be obtained in any market in which lake fishes are sold.

78. Coregonus artedi Le Sueur. Common Lake Herring. (M. V. 362 ; Argyrosomus clupeiformis Nelson 44.)

Very abundant in Lake Michigan, and probably found in some of the small lakes in the northeastern part of the state.

79. Coregonus hoyi (Gill) Jor. Moon-EYed Cisco, Cisco of Lake Michigan. (M. V. 362; Argyrosomus hoyi Nelson 44.)

Not rare, in the deeper waters of Lake Michigan, but not often seen in the fish markets.

80. Coregonus clupeiformis (Mitchill) Milner. Common White Fish. (M. V. 362 ; Coregonus albus Nelson 44.)

Very abundant in Lake Michigan.

81. Coregonus quadrilateralis Rich. Round Fish, Menomonee White Fish, (M. V. 362.)

This species is frequently taken in Lake Michigan.

Family HYODONTID $Æ$, (the Moon-eyes.)

Genus HYODON, Le Sueur.

82. Hyodon tergisus Le Sueur. Common Moon-eye, Toothed Herrina. (II V. 277; Nelson 44.)

Very common throughout the state in all large bodies of water. Cairo, Peoria. 
Family DOROSOMATID E, (the Gizzard Shad.)

Genus DOROSOMA, Rafinesque.

83. Dorosoma cepediumum (Le S.) var. heterumum (Raf.) Jor. GizzarD Shad, Hickori Shad. ( M. T. 279; Dorosoma notatum Nelson 44.)

Abundant in all the larger streams, and escaped through the canals into Lake Michigan. Ohio R. at Cairo, Ill. R. at La Salle, Pekin and Peoria.

\section{Family CLUPEID $Æ$, (the Herrings.)}

Genus POMOLOBUS, Rafinesque.

84. Pomolobus chrysochloris Raf. SkIp Jack, Oнiо Sнad. (II. V. 2:9; Nelson 44.)

Found in all the larger streams and escaped into Lake Michigan. Cairo, Henry.

Genus ALOSA, Cuvier.

85. Alosa sapidissima (Wilson) Storer. Common Shad. (M. V. 278; Nelson 41.)

Introduced into soíne streams.

\section{Suborder EVENTOGNATHI.}

\section{Family CYPRINID E.}

Genus CAMPOSTOMA, Agassiz.

86. Campostoma anomalum (Raf.) Ag. Stone LugGer. (M. V. 288, Nelson 44.)

Everywhere very abundant, ascending every small brook in the spring. Yermilion R., La Sulle Co.; Ruck R, Ogle Co. and Pine Cr., Union Co.

Genus PIMEPHALES, Rafinesque.

87. Pimephales promelas Raf. Fat-head, Black-Head. (N. V. 288; P. promelas and P. milesii Nelson 45.)

Found throughout the state, but probably not generally abundant. Bailey's Cr., La Salle Co.: Rock R., Ogle Co.

Genus H YBORH YNCHUS, Agassiz.

88. Hyborhynchus notatus (Raf.) Ag. Buent-xosed Minnow. (M. V. 288; Nelson 45.)

Generally abundant, especially in the northern part of the state. Southward its place is taken by the next, if the two be really distinct. Mackinaw Cr., Woodford Co.; McLean Co.; Rock R., at Oregon: Little Wabash, Effingham; Ill. R., Peoria ; Crystal L., Kane Co. 
89. Hyborhynchus superciliosus Cope. (M. V. 289.)

Very abundant in the bottoms of Johnson and Union counties, and in the southern part of the state generally. It is very close to the preeeding, and may not be really different. Cache $R$. and Clear Cr., Union Co.; Rock R., Ogle Co.

Genus HYBOGNATHUS, Agassiz.

90. Hybognathus argyritis Grd. Silvery Minnow. (M. V. 239; Nelson 45.$)$

Abundant in the southern third of the state. Bottoms of Johnson and Union counties; Wabash River; Ohio River; Peoria.

91. Hybognathus nuchalis Agassiz. Buunt-Jawed Minnow. (M. V. 289 ; Nelson 45.)

Wabash R. "A few specimens in the state collection from central Illinois." (Nelson.) The distinctions between this species and the preceding do not appear to be very elear. Normal, Pekin.

Genus ALBURNOPS, Girard.

(Iylopsis Cope, not of Ag.)

92. Alburnops storerianus (Kirt.) Jor. StoreR's Hinnow. (M. V. 290; Nelson 46.)

Rather frequent in Lake Miehigan and in the smali lakes of northern Indiana. Peoria, Chicago.

93. Alburnops hudsonius (Clint) Jor. Spawn Eater. (M. V. 290 ; Nelson 46.) L. Mich., Ill. R.

94. *Alburnops tuditanus Cope. (M. V. 290; Nelson 46.)

Found by Prof. Cope in various tributaries of Lake Michigan and of the Wabash in Indiana. The species is unknown to me.

[95. Alburnops nulilus Forbes, n. s.

Twenty specimens from Rock R., in Ogle Co., approaching H. spectrunculus, are not referable to any species or description of the group Alburnops, (M. V., Hybopsis Jordan \& Copeland's Cheek-list) to which they undoubtedly belong.

The mouth is inferior and horizontal; the tecth are in one row, 4-4, but slightly hooked, with large masticatory surface, and the dorsal is over the ventrals.

The length is $2 \frac{1}{4}$ inches to the caudal. Depth $3 \frac{3}{4}$ to 4 in length, head $4 \frac{1}{2}$, eye 3 in head, nose $3 \frac{2}{3}$, interorbital space 3 to $3 \frac{1}{2}$. The depth of the head is contained $6 \frac{1}{2}$ to 7 times in the head and body.

D I-8, A I-9. Scales 5-37-3, 14 before D. The lateral line is deflexed on the anterior fourth. The deep body, narrow head and large eye, 
are the consprcuous characters. The color is unusually dusky, a broad dark lateral band extends forward over the opercle through the eye to the tip of the nose. There is no candal spot, and all the fins are plain. S. A. F.]

96. Alburnops straminurus Cope. Straw-colored Minnow. (M. T. 2991; Nelson 46.)

Probably common in the southern two-thirds of the state. The only specimens noticed by me were from McLean, Crawford and Union Counties.

97. Alburnops microstomus (Raf.) Jor. (M. T. 291.)

Specimens apparently of this species, from Clear Creek, in Union County. It occurs in the streams of Kentucky.

98. Allurnops volucellus Cope. (MI. V. 291; Nelson 46.)

Specimens collected by Professor Copeland in the liock and Pecatonica Rivers.

99. Alburnops fretensis Cope. (II. T.292: Nelson 47.)

Specimens are in the collection from Rock River, and from McLean Co. Pine Cr. and Rock R., Ogle Co.; Henry, Normal.

100. Alburnops hrmaturus Cope. (M. T. 292: Nelson 47.)

Several specimens are in the collection from the Illinois River at Peoria.

Genus LUXILL'S, Rafinesque.

101. Luxilus cornutus (Raf.) Jor. SHiver. (II. V. 293; Nelson 47.)

The commonest fish in the state, occurring by thousands in every stream. Mackinaw Cr., MeLean Co.: Rock R., Ogle Co.; Pine Cr.; Ill. R., Pekin; Effingham; Cache R., Union Co.; Johnson Co.; Crystal L., Kane Co.

Genus PHOTOGENIS, Cope.

102. Photogenis analostanus (Grd.) Jor. Silver Fin. (I. V. 294: Cyprimella analostana Nelson in Errata; Cyprinella galactura Nelson 47.)

Everywhere abundant, perhaps most so in the valley of the Wabash. McLean Co.; very common in Rock R., Ogle Co.; Effingham: Peoria; Union $\mathrm{Co}_{0}$.

Genus CYPRINELLA, Girard.

103. Cyprinella forbesi Jordan (sp. nov.) Forbes' Red Fin.

A small deep, strongly compressed spccies, belonging to the group called by Girard Moniana, ${ }^{\circ}$ and related to the species called complanata, gibbosa, etc. Body oblong, elevated, strongly compressed, the depth great- 
est just in front of the dorsal fin, contained 3 times in the length to base of caudal; caudal peduncle moderately slender. Head rather stout and deep, $3 \frac{3}{3}$ in length of body; its uppor outline depressed, the nape elevated, so that the profile is somewhat concave; thickness of head through the cheeks, greater than the thickness of the body. Mouth tolerably large, quite oblique, the lower jaw slightly included. Eye not large, its length about 4 in head.

Scales, as usual in the genus, closely imbricated. Lateral line strongly decurved, with 35 scales in its course, six rows above it, and about two below. Thirteen scales in front of the dorsal.

Dorsal fin inserted just behind beginning of ventrals, about half higher than long, its rays I-7; anal fin somewhat elevated in front, its rays I-8; its anterior rays rather longer than the base of the fin. Caudal fin moderate, widely forked. Pectorals barely reaching the ventrals; ventrals barely reaching anal.

Teeth 4-4, hooked, sharp-edged, the edges of the teeth somewhat crenate.

Head and ante-dorsal region in the male fish covered with rather small white prickles, larger than in the genus Lythrurus; caudal peduncle corered below the lateral line with similar tubercles. Chin with a few prickles.

Colors, in spirits bluish above, pale below, a vague dark shoulder blotch; upper part of dorsal dusky; lower part of anal and ventrals somewhat milky.

In life the colors are as follows, according to Professor Forbes: General color steel-blue with a reddish tinge, a crescent shaped mark of a violet blue color behind the shoulders, followed by a crimson crescent; belly orange red; anal and caudal blood red.

Length of adult $2 \frac{3}{4}$ inches.

Many specimens obtained by Professor Forbes in clear streams of southern Illinois, a few from mud-holes on the bottoms.

This species resembles the figures given of Moniuna complanata and M. gibbosa Girard, but the known inaccuracy of those figures and the utterly slovenly character of the accompanying descriptions, prevents any attempt at the identification of our specimens with them. Girard's specimens were from the Rio Grande, and "on general principles" are probably different. Those interested in knowing the character of Dr. Girard's work on the smaller Cyprinidre cannot do better than to read his description of Moniana rutila and Moniana gracilis and then, as suggested by Dr. Gunther, to compare the figure of Moniana frigida given in the Pacific R. R. Surveys, (1858) with that of the same species drawn by the same artist in the Mexican Boundary Survey (1859.) All the fishes drawn by this artist at one "sitting," are cast in the same mould regardless of the appearance of the fish from which they were drawn.

Most of the types of Girard's Cyprinelle are lost. The others can only be identified almost at random by future students of Texan ichthyology.

Since writing the above, I have examined specimens of Moniana complanata Grd. (Moniana gibbosa Grd.) from the Rio Grande, C. forbesi, though closely related is unquestionably. distinct, the form of the profile being notably different. 
Genus LYTHRURUS, Jordan.

\section{Lythrurus atripes Jordan. (sp. nov.) Compressed Red-Fin.}

Body moderately elongate, very strongly compressed and elevated, the greatest depth about $3 \frac{1}{3}$ in length; head comparatively pointed; somewhat depressed above, so that an angle is formed at the occiput; length of head about $3 \frac{3}{4}$ in that of body; mouth rather large, quite oblique, the maxillary reaching about to the front of the eye; the lower jaw slightly projecting beyond the upper; eye small, smaller than in the other Lythruri, 4 in head, rather shorter than the snout.

Scales of the usual type in the genus, very closely imbricated, their exposed surfaces notably liigher than long, especially anteriorly. Lateral line very strongly decurved; scales $8-44-3$. Dorsal fin beginning about midway between ventrals and anal, rather high anteriorly, its rays $I-7$, anal rays I-11. Pectorals not quite reaching ventrals, the latter just to vent.

Color in spirits dusky bluish or livid, much as in $L$. cyanocephalus; no traces of the vertical bars sometimes noticed in $L$. diplxmius, each scale with many fine black punctulations. Coloration of fins peculiar, the usual dusky spot at the base of the dorsal in front, this spot smaller than in the other species, a black transverse bar across the upper part of the dorsal; anal similarly colored to the dorsal, the markings paler. In $L$.diplxmius the anal fin is plain. Tips of ventrals dusky, belly and lower fins probably crimson in males in the spring; male specimens profusely covered on head, front of back, sides of body anteriorly, and on lower jaw with small white tubercles as in the other species of the genus.

Length of types $2 \frac{1}{2}$ to 3 inches. Collected by Prof. Forbes in various streams in Union and Johnson counties.

The four species now known of this genus, atripes, cyanocephalus, diplemius and arden., are closely related, but may be readily distinguished when compared. Ardens is most elongate and looks somewhat like a $\mathrm{No}_{0}$ tropis; cyanocephahus, small and short, resembles Pimephules; atripes has the suallest eye and the most compressed body. The coloration of the lower fins will probably always distinguish it.

105. Lythrurus diplemins (Rafinesque) Jordan. ReD Fin. (M. V. 295; Nelson 47.)

Abundant in the southern two-thirds of the state, especially in tributaries of the Wabash and the Ohio. Mackinaw Cr., Mcliean Co.; Normal; Effingham; Union Co; Rock R., Ogle Co.; Peoria.

[var. gracilis Forbes.

Length $2 \frac{1}{2}$ to 3 in, depth $4 \frac{3}{4}$ in length, head $4 \frac{1}{2}$, eye $3 \frac{1}{3}$ in head, nose 3, D, I-8, A, I-10. Scales 8-48-4. Dorsal and anal fins marked as in atripes. Several specimens from Rock R., Ogle Co. S. A.F.]

106. *Lythrurus cyanocephalus Copeland. Hor's ReD Fish. (II. V. 295 ; Nelson $4 \overline{7}$.)

Professor Copeland's types werc from Root River at Racine. Others have been taken in tributaries of Rock R. near Beloit, within a few miles of the state line. 
Genus NOTROPIS, Rafinesque.

107. Notropis rubrifrons (Cope.) Jordan. Rosy faced Minnow. (M. V. 296; Minnilus rubrifions Nelson 47.)

Abundant in the Ohio and Wabash vallies. I have examined specimens from Rock River, and Mr. Nelson gives it from tributaries of the Illinois. Oregon; Ill. R.

108. Notropis atherinoides Raf. Emerald Minnow. (Notropis rubellus, dinemus and dilectus M. V. 296; Hinnilus dilectus, anabilis, rubellus and dinemus Nelson 46, 47.)

Everywhere very abundant, eaught by the thousand for bait off the wharves at Chicago. The species termed dinemus, rubellus, jaculus, arge, dilectus, and amalilis, seem to shade into one another in the most exasper-. ating way, and until some permanent character is shown, I propose to drop the farce of considering them as distinet, and to adopt for all the oldest specific name applied to one of the type, viz: atherinoides Raf. The species as thus defined, is a very variable one, but not more so than Luxilus cornutus, Semotillus corporalis, Campostoma anomahm or Ceratichthys biguttatus, all species of similarly wide distribution. Normal, Geneva, Pine Cr., Chicago, Henry, Union Co., Peoria, Oregon, Ill.

Genus EPISEMA, Cope \& Jordan.

109. * Episema ariomma (Cope) Jor. Big-eyed Shiner. (Cliola ariomma M. V. 298.)

White River, Indiana, abundant in still places in the river; not yet recognized elsewhere, though donbtless occurring in Illinois.

110. *Episema srabriceps Cope. Rough-headed Shiner. (Cliola scabriceps II. V. 298; Photogenis scabriceps Nelson 47.) White River; not yet noticed in Illinois.

[111. Episema jejuna Forbes, n. s.

A number of specimens, from the $111 . R$., of a pale fish of rather slender and graceful form have been assigned to this genus with some doubt. The irregularly beveled face of the pharyngeal teeth simulates a masticatory surface, although the extreme edge is more or less crenate. The teeth are distinctly hooked, 1 or $2,4-4,1$ or 2 , (in one case, apparently abnormal, 5,2 .) The dorsal begins a little before the ventrals; the mouth is large and oblique, the upper jaw (from middle of front margin to tip of maxillary) being contained 3 times in the head.

The total length of my largest specimens is 3 inches. Depth $4 \frac{2}{3}$ in length to caudal, head 4 ; eye $3_{3}^{2}$ in head, equal to nose, interorbital space $2 \frac{2}{3}$ in head; depth of head in length to caudal 6 or 7 times.

The scales are 5-37-3, with 15 or 16 before the dorsal. The lateral line is decurved on the anterior fifth. 
D. I-8, $\frac{3}{3}$ as long as high, anterior rays nearly or quite 3 times as long as posterior. The front of the fin is about equidistant from nose and middle of base of caudal. The anal has 1 spine and 7 soft rays, and is about $\stackrel{?}{5}$ as long as high.

The caudal is deeply forked. The head is nearly flat above, the nose blunt and regularly rounded.

Color in alcohol pale, with a broad silvery band overlying a plumbeous shade on sides. The dorsal is sometimes clouded with minute black specks, and the belly (usually colorless) is occasionally rosy-tinted. S. A. F.]

This species and the two preceding belong to a group termed Episcma by Cope and Jordan, and distinguished from Cliola proper by the usual presence of teeth 2,4-4, 2, instead of 4-t. Episema should probably be restored to generic rank. D.S. J.

Genus ERICYMBA, Cope.

112. Ericymba buccata Cope. Silver-Mouthed DAce. (M. V. 299 ; Nelson 45.)

Very abundant in White River and other tributaries of the Wabash, with sandy or gravelly bottoms. Several specimens from the Little Wabash, at Effingham.

Genus PHENACOBIUS, Cope.

113. Phenacolius scopiferus (Cope) Jordan. (H. V. 299; Phenacobius teretulus var. liostemus Nelson 46.)

Small streams in McJean Co.

Genus GILA, Baird \& Girard.

114. Gila elongata (Kirt) Jordan. Rei-sided Minnow. (M. T. 300 ; Nelson 47.)

Northern part of the state chiefly. Rock River, Lake Michigan.

Genus NOTEMIGONUS, Rafinesque.

115. Notemigonus chrysoleucus (Mitch.) Jor. Shiner, Brean. (II. T. 301 ; Notemigonus americanus Nelson 48.)

Everywhere very abundant in ponds and bayous. The most tenacious of life of the Minnows. Pekin, Normal, Effingham, Henry, Union Co., Ogle Co.

Genus CHROSOMUS, Rafinesque.

116. Chrosomus erythrogaster Rafinesque. Red-Bellied DACE. (M. T. 302 ; Nelson 47.)

Abundant in all small clear streams, especially in the northern part of the state. Normal; Vermilion R., La Salle Co.; Rock R., Ogle Co. 
Genus PHOXINUS, Rafinesque.

117. Phoxinus neogæus Cope. New World Minnow. (M. V. 302. Nelson 47.)

"A single specimen obtained in the Fox River at Geneva" (Nelson.) Specimens also from Wisconsin River.

Genus HEMITREMIA, Cope.

118. Hemitremia heterodon Cope. (M. V.303; Nelson 47.)

Abundant in northern Illinois and Wisconsin. Lake Michigan; Calumet R.; Fox R.; Rock R.; Bailey's Cr., La Salle Co. This species has the teeth 4-4 and should probably be referred to $\mathrm{Al}$ burnops.

Genus SEMOTILUS, Rafinesque.

119. Semotilus corporalis (Mitch.) Putnam. Chub, Creek Chub, Horned DaCe. (M. V. 304; Nelson 45.)

Everywhere very abundant, frequenting small creeks, commonest of fishes. McLean Co.; Ogle Co.; Jackson Co.; Pekin ; Effingham; Union Co.

Genus CERATICHTHYS, Baird.

120. Ceratichthys biguttatus (Kirt.) Girard. Horned Chub, Hornyhead, River Chub. (M. V. 305 ; Nelson 45.)

Everywhere very abundant, frequenting the river channels more than the preceding species. Rock R., Ogle Co.

121. Ceratichthys amblops (Raf.) Girard. Big-eyed Chub. (M. V. 306.) Abundant in the Wabash valley.

122. Ceratichthys dissimilis (Kirt.) Cope. Spotred Shiner. (M. V. 306 ; Nelson 45.)

In tributaries of the Wabash and Illirois, frequenting the river channels. Probably abundant. Rock R., Ogle Co.

Genus COUESIUS, Jor., Mss.

123. Couesius prosthemius Cope. IaAke Chub. (M. V. 307.)

In Lake Michigan. Specimens in the National Museum from near Evanston.

Genus RHINICHTHYS, Agassiz.

124. Rhinichthys cataractæ (C. \& V.) Jor. Long-nosed Dace. (M. V. 307; Rhinichthys nasutus and R. maxillosus Nelson 45.)

In clear tributaries of Lake_Michigan. Chicago. 
125. Rhinichthys obtusus Agassiz. BRown-Nosed DACE. (M. V. 308; Rhinichthys atronasus and R. lunatus Nelson 45-46.)

Found throughout the state in elear streams and "spring runs." The distinctions between this speeies and the eastern $R$. atronasus do not seem to be very important. Oregon, Ill.

126. Rhinichthys meleagris Agassiz. (II. V. 308; Nelson 46)

Streams of central and western Illinois. Vermilion River, BaiCreek, La Salle Co.; McLean Co. Prof. Agassiz's types were from the Mississippi River.

Genus CARASSIUS, Nilsson.

127. Carassius auratus (L.) Bleeker. GoLd-Fish. (M. V. 308; Nelson 48.)

Naturalized in some streams. Peeatonica R., Freeport.

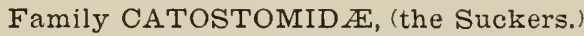

Genus PLACOPHARYNX, Cope.

128. Placopharynx carinatns Cope. (M. V. 311; Nelson 49.)

I have two young specimens of this species from Illinois River, and a pair of the stout pharyngeal bones from the Wabash River at Terra Haute. It is said by fishermen to be rather common in the Wabash River.

Genus MYXOSTOMA, Rafinesque.

129. Myxostoma carpio (Cuv. \& Val.) Jordan. White Lake Mullet. (II. V. 312; Teretulus carpio Nelson 49.)

In Lake Michigan, and the larger rivers. Probably not very common.

130. Myxostoma macrolepidotum (Le S.) Jordan. Common Mullet. (M. V. 313; Teretulus macrolepidotum Nelson 49.)

Lake Michigan, ete. Ill. R, at Ia Salle, Rock R.

Var. duquesnii (Le S.) Jor. Connon Red Horse, Mullet, White Sucker. (M. V. 313 ; Teretulus duquesnii Nelson 49).

Everywhere very abundant, aseending all the streams in the spring. Rock R, Ogle Co.; Pekin ; Cache R., Union Co.; Mackinaw Cr.; Little Wabash.

131. Myxostoma aureolum (Le S.) Jor. Sirald-headed Mullet, Golden Red Horse. (II. V. 314; Teretulus aureolus Nelson 49.)

Abundant throughout the state in the larger bodies of water, especially northward. Pekin, Peoria. 
132. * Myxostoma anisurum (Raf.) Jor. Long-Tailed Sucker. (M. V. 315.)

Abundant in Ohio River near Cincinnati; not yet noticed in Illinois.

133. Myxostoma velatum (Cope) Jor.. Small-Mouthed Red Horse, White Nose. (M. V. 317 ; Teretulus anisurus and T. velatus Nelson 49.)

Generally abundant in the larger streams.

Genus MINYTREMA, Jordan.

134. Minytrema melanops (Raf.) Jor. Spotted Sucker. (M. V. 318 ; Erimyzon melanops Nelson 48.)

Generally abundant, especially southward.

Genus ERIMYZON, Jordan.

135. Erimyzon sucetta (Lac.) Jord. Chub-sucker, Creek-Fish. (M. V. 319; Erimyzon oblongus Nelson 48.)

Everywhere very abundant, ascending small streams in spring. Union Co., Johnson Co.

Genus CATOSTOMUS, Le Sueur.

136. Catostomus nigricans Le S. Stone-roller, Hog Sucker, Crawla-вottom, Hammer-head. (1I. V. 319 ; Nelson 48.)

Everywhere common, frequenting rapids and shallows in clear streams. Rock R., Ogle Co.; Mackinaw Cr.

137. Catostomus commersonii (Lac.) Jor. Common Sucker, White Sucker. (M. V. 320; Catostomus teres Nelson 48.)

Everywhere very abundant. Ill. R., Mackinaw Cr., Pine Cr.; Cache R., Union Co.; Rock R.

138. Catostomus longirostrum Le Sueur. Red-SIDed Sucker, Longnosed Sucker. (M. V. 320; Catostomus hudsonius Nelson 48.)

Abundant in Lake Michigan.

Genus CYCLEPTUS, Rafinesque.

139. Cycleptus elongatus (Le S.) Ag. Gourd-SeEd Sucker, Blackhorse, Missouri Sucker. (II. V. 320 ; Nelson 50.)

In the Ohio and Mississippi Rivers, and all their larger tributaries; not generally common, but often seined in large numbers. Peoria, Ill. 
Genus CARPIODES, Rafinesque.

140. ('arpiodes velifer (Raf.) Ag. Spear-Fish, SaIL-Fish, Skim-Back, QuilL-BACK. (II. V. 321: Ichthyolnes velifer Nelson 49.)

Generally common in the larger streams. Peoria.

141. C'arpiodes selene Cope. Moon Carp-sucker. (MI. V. 321.)

Abundant in Lake Michigan. The distinctions between this species and the next do not seem to be very important.

142. C'arpiades cutisanserinus Cope. LONG-FINNED CARP-SUCKer. V. 321.)

(1I.

Generally abundant in the larger tributaries of the Ohio. Rock R., at Oregon, Ill.

143. Carpiodes difformis Cope. Deformed CARP-SuCker. (M. V. 321; Ichthyolus difformis Nelson 49.)

Numerous specimens in the collection from Illinois River. Professor Cope's types came from the Wabash. Heary, Ill.

144. Carpiodes bison Agassiz. Buffalo Carp-sucker. (M. V. 322 ; Ichthyobus bison 49. .)

"Found in the larger rivers." (Nelson.)

145. Carpiodes cyprinus (Le S.) Ag. Silvery Carp-sucker. (M. V. 322.)

Specimens apparently identical with this eastern species are in the state collection from Illinois River. Henry, Ill.

146. Carpiodes thompsoni Agassiz. LAKe CARP-SUCKER. (M. V. 322; Ichthyobus thompsoni Nelson 49.)

The specimens from Lake Michigan noticed by Mr. Nelson, are in the collection. Henry, Ill.

147. Carpiodes carpio (Raf.) Jordan. River Carp-sucker. (M. V. 322; Ichthyolus carpio Nelson 49.)

Speeimens from Wabash River and from the Ohio at Cairo.

Genus ICHTHYOBUS, Raf.

148. Ichthyolus bubalus (Raf.) Ag. Brown Buffalo, Red Mouti. (I. V. 322; Nelson 49.)

Specimens examined from Wabash River and from the Illinois at Peoria, where it is the most abundant buffalo fish. Peoria, Henry, and McLean Co.

Genus BLBALICHTHYS, Agassiz.

149. Bubalichthys urus Ag. Black Buffalo, Big-Moutined Buffalo. (Bubalichthys niger Ni. V. 323 ; Nelson 50.)

Mississippi River at Quincy. Probably generally abundant in the larger streams. Peoria. 
150. Bubalichthys cyanellus (Nelson) Jordan. SMall-Modthed BuFFALO. (Bubalichthys bubalinus and Bubatichthys altus. M. V. 325 ; Ichthyobus cyanellus Nelson 49.)

Abundant in all the larger streams throughout the state. An examination of Mr. Nelson's typical specimens shows that they are the young of the common Bubalichthys bubalus of Agassiz. As the specific name "bubalus" is hardly tenable for this species, if we conceive that the bubalus of Rafinesque is an Ichthyobus, I have lately suggested the name bubalinus as a substitute. Cyanellus has however priority over bubalinus. I therefore propose to adopt Mr. Nelson's name for this species.

\section{Order NEMATOGNATHI.}

Family SILURID $\mathbb{E}$, (the Cat-fishes.)

Genus ICHTH ELURUS, Rafinesque.

151. *Ichthæelurus furcatus (C. \& V.) Gill. Fork-TAILEd CAT. (M. V. 328.)

Ohio and Mississippi rivers; probably not common. I have seen none from within the limits of the state.

152. Ichthælurus robustus Jordan. ChUCKLE-Headed Cat. (M. V. 328 ; Ictalurus furcatus Nelson 50.)

Illinois River; probably not rare in the larger streams. Peoria.

153. Ichthxlurus punctatus (Raf.) Jordan. Common Channel Cat, Blue Cat, White Cat. (M. V. 328; Nelson 50.)

Very abundant in all the large streams throughout the state. Cairo; Pekin; Rock R., Ogle Co.; Bottoms, Union Co.

\section{Genus AMIURUS, Rafinesque.}

151. Amiurus nigricans (Le S.) Gill. Great Fork-tailed Cat, Great Mississippi Cat, Great lake Cat-Fish. (M. V. 329.)

Abundant in the Mississippi and Ohio rivers and in Lake Michigan. This species reaches an immense size and is probably the largest of all our fresh water fishes.

155. Amiurus natalis (Le S.) Gill. Yellow Cat. (M. V. 331 ; Amiurus cupreus Nelson 50.)

Everywhere more or less abundant in ponds and bayous. McLean Co.; Cache R., Johnson Co.

156. Amiurus vulgaris (Thompson) Nelson. Long-Jawed Cat. (M. V. 331 ; Nelson 50.)

Abundant in the Mississippi River at St. Louis, and in Lake Michigan. Pekin, Ill. 
157. Amiurus catus (L.) Gill. BulL-HeAd. (M. V. 332; Amiurus atrarius Nelson 332.)

Great Lakes and their tributaries. Vermilion R.; Ill. R.; MLLean Co.

158. Amiurus marmoratus (Holbrook) Jordan. Marbled Cat. jM. V. 332.)

Numerous specimens of a cat-fish, marbled in color, and not ev. idently distinguishable from $A$. marmoratus, Holbrook, were collected by Professor Forbes in southern Illinois, and one or two from Illinois River. Considerable variation is shown in the coloration, some being nearly plain, others much variegated. In one specimen, the broad head with depressed front much resembles that of $A$. xanthocephalus. In all the adipose fin is very large and the dorsal spine is quite high. Henry, Ill., Johnson Co.

159. Amiurus melas (Raf.) Jordan \& Copeland. Black Cat. (M. V. 332 ; A. confinis and A. pullus Nelson 50.)

Abundant in the streams of the southern balf of the state. McLean Co., Union and Johnson Co's., (Clear Cr., Bottoms, Cache R.)

160. Amiurus xanthocephalus (Raf.) Gill. Yellow-headed Cat. (M. V. 333; A. albiclus Nelson 50.)

Common in the southern part of the state. This is not "our commonest cat-fish" as stated by Mr. Nelson. [The specimens upon which $11 \mathrm{r}$. Nelson based this statement were labeled nebulosus in the collection (given as a synonym of albidus in M. V., first edition,) but have been identified with catus by Dr. Jordan. S. A. F.] Peoria.

Genus PELODICHTHYS, Rafinesque.

161. Pelodichthys olivaris (Rafinesque) Gill \& Jordan. Mud Cat. (M. V. 334; Hopladelus olivaris Nelson 50.)

Common in the larger streams, reaching a large size. Peoria.

Genus NOTURUS, Rafinesque.

162. Noturus flarus Rafinesque. Yellow Stone Cat. (1.. Y. 335: Nelson 50.)

Rather common, especially southward and in the larger streams.

163. Noturus exilis Nelson. Slender Stone Cat. (M. V. 335; Nelson 51.)

Besides Mr. Nelson's types, which were from McLean Co., I bave obtained specimens from Root R., Wis., and from Kansas. 
164. Noturus miurus Jordan. SAw-Spined Stone CAT. (M. V. 336 ; Noturus marginatus Nelson 50.)

Abundant, especially southward. Specimens from the Wabash and from the Cache R., in Johnson Co.

165. Noturus sialis Jordan. Chubby Stone Cat. (M. V. 337.)

Generally abundant, with the preceding. Also Ill. R. at Pekin, Cairo, Ill.

\section{Order APODES.}

Family ANGUILLID E, (the Eels.)

Genus ANGUILLA, Thunberg.

166. Anguilla rostrata (Le S.) D K. Common EeL. (M. V. 338 ; Nelson 51.)

Occasionally taken in most of the waters of the state, but not common. It is probably not indigenous in the upper lakes, having been introduced, or else having escaped through the canals from the $\mathrm{Ohio}$, or probably both. Ill. R. at Peoria.

\section{Sub-class GANOIDEI.}

\section{Order CYCLOGANOIDEI.}

Family AMIID $\approx$, (the Bow-fins.)

Genus $A M I A$, Linnæus.

167. Amia calva Linnæus. Dog-Fish, Mud-fish, Bow-Fin. (II. V. 340 ; Nelson 51.)

Abundant throughout the state in the lakes and larger streams. In the small streams it is seldom found. [Common in ponds in S. Ill., where it is generally eaten, and is known as the "Grinnel," (Gunnel ?). S. A. F.] Ponds S. Ill., Ill. R., Ohio R., Miss. R.

\section{Order RHOMBOGANOIDEI.}

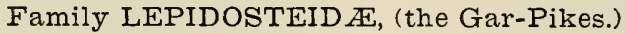

Genus LEPIDOSTEUS, Lacepede,

168. Lepidosteus osseus (L.) Ag. Gar Pike. (M. V. 342 ; Nelson 51.)

Abundant in the larger streams throughout the state. Illinois and Ohio rivers. 
169. Lepidosteus platystomus Raf. Short-nosed Gar. (M. V. 342; Nelson 51.)

Occurs throughout the state in the larger streams. It is much more abundant in tributaries of the Mississippi than in the Lake. The commonest gar in the Ill. R. Peoria, Pekin.

Genus LITHOLEPIS, Rafinesque.

170. Litholepis spatula (Lac.) Jor. Alligator Gar. (M. V. 342 ; Litholepis adamantinus Nelson 51.)

In the Mississippi and Ohio, not common, "occasionally straying up smaller rivers into the interior of the state." (Nelson.)

\section{Order SELACHOSTOMI.}

Family POLYODONTID $A$, (the Spoonbills.)

Genus POLYODON, Lacepede.

171. Polyodon folium Lacepede. Paddle-FISh, Duck-BILl, Spoon-BILl. (II. V. 344 ; Nelson 51.)

Common in all the larger streams, especially southward. Ohio R. at Cairo; Ill. R. at Pekin, Peoria, \&c.

\section{Order CHONDROSTEI.}

Family ACIPENSERID Æ, (the Sturgeons.)

Genus ACIPENSER, Linnæus.

172. Acipenser maculosus Le Sueur. Spotted Sturgeon. (M. V. 345 ; Nelson 51.)

Ohio and Mississippi rivers, probably not in the Lake.

173. Acipenser rubicundus Le Sueur. Lake Sturgeon. (M. V. 345 ; Nelson 51.)

Very abundant in the Lake; whether found in the Mississippi or not $I$ do not know.

Genus SCAPHIRHYNCHOPS, Gill.

174. Scaphirynchops platyrhynchus (Raf.) Gill. Shoved-Nosed SturGEON. (II. V. 345; Nelson 51.)

Common in the Ohio and Mississippi rivers. Ohio R., Cairo ; Ill. R., Peoria. 


\section{Class MARSIPOBRANCHII.}

\section{Order HYPEROARTIA.}

Family PETROMYZONTID

Genus AMMOCETES, Dumeril.

175. Ammocotes niger (Raf.) Jor. Small Black Lamprey. (M. V. 349 ; Petromyzon niger Nelson 52.)

Common in small streams in many places, ascending to spawn in the spring. Pecatonica R., Freeport.

176. Ammocoetes argenteus (Kirt.) Jor. Silvery LAMPrey. (M. V. 349 ; Ichthyomyzon argenteus Nelson 52.)

Probably more or less abundant through the state. Ill. R., Pekin.

177. Ammocoetes hirudo (Grd.) Jor. Leech Lamprey. (M. V. 350 ; Ichthyomyzon hirudo Nelson 52.)

A species supposed to be the one to which Girard gave the name of hirudo is quite abundant in the Mississippi and lower Ohio. * Ohio R., at Cairo.

* Where exact localities are given in the preceding paper, they are in nearly every case taken from specimens now in the Laboratory, collected by myself or my assistants. S. A. F. 